\title{
Multiple Criteria Decision Making and Prospective Scenarios Model for Selection of Companies to Be Incubated
}

\author{
Altina S. Oliveira ${ }^{1}$, Carlos F. S. Gomes ${ }^{1}{ }^{1}$, Camilla T. Clarkson ${ }^{1}$, Adriana M. Sanseverino ${ }^{1}$, Mara R. S. Barcelos ${ }^{1}$, \\ Igor P. A. Costa ${ }^{2, * \mathbb{D}}$ and Marcos Santos ${ }^{2} \mathbb{D}$ \\ 1 Production Engineering Department, Federal Fluminense University (UFF), 24210-240 Niterói, Brazil; \\ altinaoliveira@id.uff.br (A.S.O.); cfsg1@bol.com.br (C.F.S.G.); camillaclarkson@id.uff.br (C.T.C.); \\ adrianams@id.uff.br (A.M.S.); marabarceloss@gmail.com (M.R.S.B.) \\ 2 Operational Research Department, Naval Systems Analysis Centre (CASNAV), \\ 20091-000 Rio de Janeiro, Brazil; marcosdossantos_doutorado_uff@yahoo.com.br \\ * Correspondence: costa_igor@id.uff.br
}

check for updates

Citation: Oliveira, A.S.; Gomes, C.F.S.; Clarkson, C.T.; Sanseverino, A.M.; Barcelos, M.R.S.; Costa, I.P.A.; Santos, M. Multiple Criteria Decision Making and Prospective Scenarios Model for Selection of Companies to Be Incubated. Algorithms 2021, 14, 111 https://doi.org/10.3390/a14040111

Academic Editor: Francisco

Javier Santos-Arteaga

Received: 19 February 2021

Accepted: 26 March 2021

Published: 30 March 2021

Publisher's Note: MDPI stays neutral with regard to jurisdictional claims in published maps and institutional affiliations.

Copyright: (c) 2021 by the authors. Licensee MDPI, Basel, Switzerland. This article is an open access article distributed under the terms and conditions of the Creative Commons Attribution (CC BY) license (https:/ / creativecommons.org/licenses/by/ $4.0 /)$.

\begin{abstract}
This paper proposes a model to evaluate business projects to get into an incubator, allowing to rank them in order of selection priority. The model combines the Momentum method to build prospective scenarios and the AHP-TOPSIS-2N Multiple Criteria Decision Making (MCDM) method to rank the alternatives. Six business projects were evaluated to be incubated. The Momentum method made it possible for us to create an initial core of criteria for the evaluation of incubation projects. The AHP-TOPSIS-2N method supported the decision to choose the company to be incubated by ranking the alternatives in order of relevance. Our evaluation model has improved the existing models used by incubators. This model can be used and/or adapted by any incubator to evaluate the business projects to be incubated. The set of criteria for the evaluation of incubation projects is original and the use of prospective scenarios with an MCDM method to evaluate companies to be incubated does not exist in the literature.
\end{abstract}

Keywords: business incubators; Multiple Criteria Decision Making (MCDM); prospective scenarios; AHP-TOPSIS-2N

\section{Introduction}

Potential entrepreneurs seek in business incubators the necessary help to achieve success in their ventures. One way to get into an incubator is through a process that evaluates the business plan or project of the company or future business. According to [1] (p. 227), "despite some differences, all incubators sought to identify the most promising and innovative enterprises to support and stimulate the creation of new businesses". The importance of having a consistent methodology for ordering projects is emphasized by [2].

Work on incubators has focused on performance and evaluation indicators of incubated proposals and companies, but when evaluating a business or project plan, they do not mention considering prospective scenarios in their evaluations. Thus, the following question is presented: How to model the business plans or projects candidate for incubation, considering prospective scenarios under a multicriteria approach?

We investigated how the terms "prospective scenarios," "multicriteria" and "business incubators" are related or not in the literature, searching for publications in the Scopus and Web of Science databases, in December 2020. Table 1 shows the research strategies used and the results found for title-abstract-keywords. 
Table 1. Strategies and results.

\begin{tabular}{ccc}
\hline Strategies & \multicolumn{2}{c}{ Articles } \\
\cline { 2 - 3 } & Scopus & Web of Science \\
\hline "prospective scenario" AND "business incubator" & 0 & 0 \\
"prospective scenario" AND " multicriteria" & 2 & 5 \\
"business incubator" AND " multicriteria" & 1 & 2 \\
"prospective scenario" AND "business incubator" AND & 0 & 0 \\
"multicriteria" & & \\
\hline
\end{tabular}

We found ten documents adding up the results of all strategies. Table 2 presents these results, not counting the repeated documents.

Table 2. Documents in the Scopus and Web of Science databases.

\begin{tabular}{|c|c|c|c|}
\hline Title & Doc Type & Reference & Source \\
\hline $\begin{array}{l}\text { Dynamic Simulation of Forest } \\
\text { Management Normative } \\
\text { Scenarios: The Case of Timber } \\
\text { Plantations in Southern Chile }\end{array}$ & Article & [3] & Futures \\
\hline $\begin{array}{l}\text { Economic-Energy-Environment } \\
\text { Analysis of Prospective } \\
\text { Sugarcane Bioethanol } \\
\text { Production in Brazil }\end{array}$ & Article & [4] & Applied Energy \\
\hline $\begin{array}{l}\text { Prospective and participatory } \\
\text { integrated assessment of } \\
\text { agricultural systems from farm } \\
\text { to regional scales: Comparison of } \\
\text { three modeling approaches }\end{array}$ & Article & [5] & $\begin{array}{c}\text { Journal of Environmental } \\
\text { Management }\end{array}$ \\
\hline $\begin{array}{l}\text { Modeling the potential benefits } \\
\text { of catch-crop introduction in } \\
\text { fodder crop rotations in a } \\
\text { Western Europe landscape }\end{array}$ & Article & [6] & $\begin{array}{l}\text { Science of the total } \\
\text { Environment }\end{array}$ \\
\hline $\begin{array}{l}\text { The multicriteria incubator } \\
\text { selection model by considering } \\
\text { investor orientation }\end{array}$ & $\begin{array}{l}\text { Conference } \\
\text { Proceedings }\end{array}$ & [7] & $\begin{array}{c}\text { 11th International } \\
\text { Conference on Industrial } \\
\text { Management }\end{array}$ \\
\hline $\begin{array}{l}\text { Environmental assessment of } \\
\text { future technologies: how to trim } \\
\text { LCA to fit this goal }\end{array}$ & Article & [8] & $\begin{array}{l}\text { Journal of Life Cycle } \\
\text { Assessment }\end{array}$ \\
\hline $\begin{array}{l}\text { A Multidimensional Evaluation } \\
\text { of the Effectiveness of Business } \\
\text { Incubators: An Application of } \\
\text { the PROMETHEE Outranking } \\
\text { Method }\end{array}$ & Article & [9] & $\begin{array}{c}\text { Environment and } \\
\text { Planning C: Politics and } \\
\text { Space }\end{array}$ \\
\hline
\end{tabular}

As can be seen, the publications in the literature are still incipient, in addition to being relatively recent, beginning in 2009 . We found a gap in publications that include the subjects of prospective scenarios, business incubators and multicriteria. In this paper, we propose a set of criteria for evaluating proposals for incubation which represents a starting point in the literature, filling the gap.

Three different scenarios were built and as a result we developed an evaluation model that includes fifteen new criteria and prospective scenarios. The use of prospective scenarios and Multiple Criteria Decision Making (MCDM) application made it possible to sort by relevance the companies to be incubated, thus creating an unprecedented evaluating model for incubation. 
Also, we identified that, when comparing the alternatives (companies to be incubated) in the light of the established criteria, there was a strong compensatory characteristic in the data analysis. Therefore, among the various MCDM methods available, in this article we chose to apply the AHP-TOPSIS-2N method, because it is a compensatory model, with the advantage of generating two orders with the same data, providing a sensitivity analysis of the result. The method combines a concept of hierarchy with weights associated with the concept of checking how much an alternative is closer and farther from an ideal alternative.

In light of these considerations, this paper aims to develop a model to evaluate business projects to get into an incubator. This model combines prospective scenarios with a multicriteria method to rank the alternatives. We applied the Method Unified for Strategic Prospective Planning (Momentum), proposed by [10], with the AHP-TOPSIS-2N [11], a hybrid MCDM method composed by the Analytic Hierarchy Process (AHP), Technique for Order Preference by Similarity to Ideal Solution (TOPSIS) and two normalization procedures $(2 \mathrm{~N})$.

This introduction describes the objectives of the research. Section 2 presents the background. Section 3 provides the materials and methods, while Section 4 presents the methodology applied in the study. Section 5 presents the results and Section 6 concludes the research.

\section{Background}

The high mortality rate of companies of different branches in the first years of life has been discussed in the academic environment, especially the small and medium ones. In this context, the incubators of companies are inserted, which has the purpose of helping these new companies to enter the market, through an aid called consulting.

The incubation process is called the period in which the company stays inside the incubator receiving assistance, accompanied by the team that works to organize it managerially, and with that improve their chances of success and permanence, as well as good performance in the market [12].

Business incubators have several consultancies in specific areas, and also perform periodic performance evaluations in their incubated companies, using other resources and indicators. According to [13], the good performance of the incubators is considered a critical factor because it can increase the companies' chance of survival. Besides, "the extent and importance of firm activity during incubation period are also revealed by the records of inter-firm alliances and acquisitions" [14] (p. 573).

The objective of evaluating the performance of an incubated company goes beyond knowing its results. Besides, it is necessary to improve the incubation practices and the way to identify actions of continuous improvement in the management.

In a competitive and dynamic market, evaluating performance becomes increasingly necessary in the search for organizational efficiency. Contemporary society is facing a critical scenario due to the adoption of unsustainable development models [15].

It is considered of great importance to identify a method for evaluate the incubated companies, and especially the candidate companies for incubation. That is, what incubators consider important when evaluating a project or business plan of a company hiring the candidate. What criteria and/or alternatives are considered for evaluating proposals?

In addition to these issues, common to companies hiring candidates, it should be noted that the scenario in which these new companies will be inserted has dynamic and unstable characteristics. In this context, considering prospective scenarios as one of the items of the evaluation of the hatching proposals becomes of extreme importance to guide the present, aiming to obtain possible and desirable futures.

The methodology of prospective scenarios can be used in any situation of uncertainty since its objective is to identify early warning signals, to evaluate the robustness of the organization's key competencies, to generate better strategic options, and evaluate the risk/return of each option [16]. 
Also, regarding the method of evaluation of this proposal, it is important to know what tools the incubators use to aid the decision. One of the most effective ways is to use the already widespread MCDM methods.

For [17], in the life of organizations, the complex decision problems that belong to their managerial body are innumerable, considering that most real situations are characterized by the existence of several goals to be achieved. Economic, industrial, financial, political or social problems are part of this approach. When the choice of certain alternatives depends on the analysis of different points of view, called criteria, the decision problem is considered a multicriteria problem.

MCDM has a focus used as the central element of decision analysis. As such, it makes use of information about the problem (in this case, the evaluation instrument of the proposal), having as the main characteristic the analysis of several alternatives or actions, under various points of view or criteria. To make this analysis, decisions (managers of incubators and/or consultants) often must compare the alternatives present in the decision-making process [17]. MCDM proposes to clarify the problem and attempt to provide answers to the issues raised in a decision-making process, according to clearly defined models.

Pereira et al. [18] state that the adoption of a combination of methodologies, such as the proposal of this article, enables the identification of the variables and a rational analysis of the information. The academic literature contains many applications combining the AHP and TOPSIS methods, such as [19-21]. The modeling presented in this paper includes, in addition to the hybrid modeling composed of the two methods, two normalizations of the results, presenting a richer and more robust sensitivity analysis, which provides security, transparency and simplicity to the decision-making process [22].

\section{Materials and Methods}

\subsection{Momentum Method}

In this paper, we applied the Momentum method, elaborated by [10], to build scenarios. Momentum aggregates the main concepts of the methods found in the literature and includes the use of multicriteria methods for strategic decisions. The method is developed, considering the following steps:

1. System overview;

2. Mapping of relevant actors;

3. Identification of variables;

4. SWOT analysis;

5. Elucidation of uncertainties;

6. Selection of relevant variables;

7. Definition of key indicators;

8. Definition of the scenarios;

9. Definition of criteria;

10. Elicitation of alternatives;

11. Definition of the weights for each criterion of all the scenarios;

12. Evaluation of the alternatives from the point of view of each criterion;

13. Application of the classification algorithm for the collected data.

This method has been adapted to our research problem. We follow all these steps; however, we propose a new combination: Momentum with AHP-TOPSIS-2N. For model validation, we applied it to a real problem to select the companies to be incubated. Also, the weights of each criterion were established by incubator managers.

\subsection{The AHP-TOPSIS-2N Method}

The decision-making process generally involves a choice between several alternatives. The feasible alternatives of meeting the objective, and selected for evaluation, are compared according to criteria and under the influence of attributes [23]. The MCDM methods are very useful to support the decision-making process in these cases, because they consider 
value judgments and not only technical issues, to evaluate alternatives to solve real problems, presenting a highly multidisciplinary [24]. The MCDM methods have been employed to support the decision-making process in several recent complex problems, as presented in [25-30].

The AHP-TOPSIS-2N hybrid method, initially proposed by [11], consists of two MCDM techniques that are usually adopted in complex scenarios, characterized by multiple and conflicting objectives: the AHP and TOPSIS methods. To understand the method, it is necessary a prior understanding of the two techniques that compose it.

The AHP method, developed by [31], is a quantitative MCDM technique for problems, being one of the most used worldwide, due to its ease and because it is intuitive. The method is applied to obtain the weights of the criteria, through pairwise comparisons based on the Saaty fundamental scale (Table 3).

Table 3. Saaty fundamental scale.

\begin{tabular}{|c|c|c|}
\hline Degree of Importance & Definition & Explanation \\
\hline 1 & Equal importance & $\begin{array}{l}\text { The two activities contribute } \\
\text { equally to the goal }\end{array}$ \\
\hline 3 & Moderate importance & $\begin{array}{l}\text { Experience and judgment } \\
\text { slightly favor one activity over } \\
\text { another }\end{array}$ \\
\hline 5 & Strong importance & $\begin{array}{l}\text { Experience and judgment } \\
\text { strongly favor one activity } \\
\text { over another }\end{array}$ \\
\hline 7 & Very strong importance & $\begin{array}{l}\text { One activity is strongly } \\
\text { favored over another; element } \\
\text { is very dominant as shown in } \\
\text { practice }\end{array}$ \\
\hline 9 & Extremely important & $\begin{array}{l}\text { The evidence is in favor of one } \\
\text { activity over another, to the } \\
\text { greatest extent possible }\end{array}$ \\
\hline $2,4,6,8$ & $\begin{array}{l}\text { Intermediate values between } \\
\text { two judgements }\end{array}$ & $\begin{array}{l}\text { They are used to express } \\
\text { preferences that are between } \\
\text { the values of the above scale }\end{array}$ \\
\hline
\end{tabular}

One of the advantages of the AHP method is the possibility to identify the inconsistencies of decision-makers (DM). A Consistency Ratio (CR) less than 0.10 is considered acceptable, while a $\mathrm{CR}$ greater than 0.10 generates the need for the decision-taker to make assessments or judgments again [32].

The TOPSIS method, presented by [33], orders the alternatives according to the proximity of the Positive Ideal Solution (PIS). The best alternative is the one that is closer to the PIS and the farthest from the Negative Ideal Solution (NIS). TOPSIS is a method that, after being applied in solving problems of the multicriteria type, results in an ordering of the existing alternatives. This ordering is based on the idea that the best alternative should be the one that presents minimum distance to the ideal solution "PIS" and maximum distance to the solution anti-ideal or "NIS". The method aims to generate a decreasing ordering of the coefficients of the calculated distances. This coefficient is known in the literature as relative proximity. Several decision problems can be solved with TOPSIS, being these of the only type decider or decision in group [34].

TOPSIS can be approached individually, based on precise input data previously determined by the DM, as well as with other methods in the literature. In situations where the lack of information is present in the problems, TOPSIS should be integrated with other approaches to its application [34].

For the application of the AHP-TOPSIS-2N method, Souza et al. [11] defined nine steps, described below: 
1. Establishment of the Decision Matrix, expressing the score of each alternative in each criterion analyzed;

2. Preparation of the Weighting Matrix, using the Saaty fundamental scale (Table 3), by evaluating alongside each criterion;

3. By applying the AHP method, the weights of each criterion are obtained. The importance of calculating CR should be less than 0.1 to ensure the consistency of the analysis;

4. Obtaining the standard decision matrix: The four standardization procedures most used in the literature are described by [11] as explained below:

- $\quad$ Standardization procedure $\mathrm{N}_{1}$ : by using the maximum value of the scores (1).

$$
p_{i j}=\frac{x_{i j}}{\max x_{i j}} \text { where } i=1, \ldots, m \text {; and }, j=1, \ldots, n \text {. }
$$

- Standardization procedure $\mathrm{N}_{2}$ : by using the ratio between the difference of the scores and the minimum value of the scores, and the difference between the maximum value and the minimum value of the scores (2).

$$
p_{i j}=\frac{x_{i j}-\min x_{i j}}{\max x_{i j}-\min x_{i j}}, \text { where } i=1, \ldots, m ; \text { and }, j=1, \ldots, n \text {. }
$$

- $\quad$ Standardization procedure $\mathrm{N}_{3}$ : by using the sum of the scores (3).

$$
p_{i j}=\frac{x_{i j}}{\sum_{i=0}^{m} x_{i j}} \text {, where } i=1, \ldots, m \text {; and }, j=1, \ldots, n \text {. }
$$

- Normalization procedure $\mathrm{N}_{4}$ : by using the square root of the sum of the squares of the scores (4).

$$
p_{i j}=\frac{x_{i j}}{\sqrt{\sum_{i=0}^{m} x_{i j}^{2}}}, \text { where } i=1, \ldots, m ; \text { and }, j=1, \ldots, n \text {. }
$$

We emphasize that, in this study, all four normalization procedures mentioned were tested, but only two of them had consistent results in terms of the order of alternatives. As such, the AHP-TOPSIS-2N method considers the normalization procedures $\mathrm{N}_{2}$ (Equation (2)) and $\mathrm{N}_{4}$ (Equation (4)). Normalizations $\mathrm{N}_{1}$ and $\mathrm{N}_{3}$ gave many discrepant results, corroborating with the results obtained by [11], who identified the most appropriate normalizations to the hybrid methodology.

5. Construction of the Weighted Standard Decision Matrix: weighted matrices are obtained by multiplying the weights calculated in step III by the normalized matrices:

6. $\quad$ Obtaining the PIS (A+) and NIS $(\mathrm{A}-)(5)$ :

$$
A^{+}=\left\{p_{1}^{+}, p_{2}^{+}, \ldots, p_{m}^{+}\right\} ; \quad A^{-}=\left\{p_{1}^{-}, p_{2}^{-}, \ldots, p_{m}^{-}\right\}
$$

It is important to note that, for criteria of the cost type, the PIS will be the smallest module value, and the NIS will be the value of the highest absolute value (6).

$$
A^{+}=\left\{p_{1}^{-}, p_{2}^{-}, \ldots, p_{m}^{-}\right\} ; \quad A^{-}=\left\{p_{1}^{+}, p_{2}^{+}, \ldots, p_{m}^{+}\right\}
$$

7. Calculation of the Euclidean distances of each of the alternatives to PIS (D+) and NIS (D-) (7) and (8):

$$
D^{+}=\sqrt{\sum_{j=1}^{n} w_{j}\left(d_{i j}^{+}\right)^{2}}
$$




$$
D^{-}=\sqrt{\sum_{j=1}^{n} w_{j}\left(d_{i j}^{-}\right)^{2}}
$$

where $d_{i j}^{+}=P_{j}^{+}-P_{i j}$, with $\mathrm{i}=1, \ldots$, m.e $d_{i j}^{-}=P_{j}^{-} P_{i j}$, with $\mathrm{i}=1, \ldots, m$.

8. Calculation of proximity to the ideal alternative (8):

$$
\mathrm{C}=\frac{D_{i}^{-}}{D_{i}^{+}+D_{i}^{-}}
$$

9. Ordering preferences.

\section{Results}

\subsection{Step 1-System Overview}

The concept of incubation seeks an effective means of linking the capital, technology and know-how to leverage entrepreneurial talent, accelerate the development of new enterprises and thus the speed of technology exploitation. Incubators assist emerging companies by providing a variety of support services such as assistance in business development and marketing planning, construction of management teams, raising capital and access to several other more specialized services [35]. In this way, the incubated companies enjoy all the necessary infrastructure for their development so that, when competing in the market, they have the necessary knowledge and experience to an emerging company [36].

According to [37], the strongest upward curve in the growth path of incubated companies is mainly due to four factors: (i) the development of credibility; (ii) shortening the learning curve of the entrepreneurs; (iii) faster problem solving; and (iv) access to a network of entrepreneurial relationships.

It can be said that companies that undergo incubation programs are better able to survive in the high competition market since, in qualifying entrepreneurs and enterprises, the graduated companies (which have already gone through the incubation process) have competitive differentials that provide greater survival capacity over time. Incubator managers point out that access to knowledge, mentoring, technology and management skills form the most successful entrepreneurs and companies [37].

\subsection{Step 2-Mapping of Relevant Actors}

The main actors of the system under analysis are the stakeholders who participate and maintain links with the incubator and the incubated companies. Table 4 shows the main stakeholders and their respective influences and expectations about the system.

Table 4. Main stakeholders.

\begin{tabular}{ll}
\hline Stakeholders & Description \\
\hline \multirow{3}{*}{ Entities and regulatory companies } & Incubator \\
& SEBRAE \\
& ANPROTEC \\
\hline \multirow{2}{*}{ Universities } & Technology Sources \\
& Search sources \\
& Brands and patents \\
\hline Government & Development News \\
\hline \multirow{2}{*}{ Local community } & Community Involvement to Promote \\
\hline & Entrepreneurship \\
\hline \multirow{2}{*}{ "Mentors" } & Partnerships with the private sector in the \\
& areas of mentoring (marketing/mentoring) \\
& and marketing Accelerators \\
& Investor angels \\
\hline
\end{tabular}




\subsection{Step 3-Identification of Variables}

We identified the variables of the system (business incubation), considering the literature review and steps 1 and 2 of the Momentum method:

- $\mathrm{V}_{1}$-Economic/political crisis;

- $\mathrm{V}_{2}$-Access to specific edicts for development;

- $\mathrm{V}_{3}$-Exchange variation;

- $\mathrm{V}_{4}$-Access to specific credit sources/partnerships;

- $\mathrm{V}_{5}$-Initial financial investment;

- $\mathrm{V}_{6}$-Strategic relations with universities and research sources;

- $\mathrm{V}_{7}$-Patent development;

- $\mathrm{V}_{8}$-Incentives from agencies like SEBRAE and ANPROTEC;

- $\mathrm{V}_{9}$-Number of clients;

- $\mathrm{V}_{10}$-Infrastructure and quality services offered by the incubator.

\subsection{Step 4-SWOT Analysis}

The SWOT matrix is the general analysis of the internal environment (strengths and weaknesses) and the external environment (opportunities and threats) of an organization. Based on the knowledge about incubated companies, a SWOT matrix was a framework for a better understanding to allow the formulation of possible strategies.

Table 5 does not represent the SWOT matrix of a specific company, but rather, in general, the main strengths, weaknesses, opportunities and threats that any incubated company may have. From the analysis made, it can be said that, when a company becomes incubated, it starts to have opportunities

Table 5. SWOT matrix.

\begin{tabular}{|c|c|c|}
\hline \multirow[b]{2}{*}{ 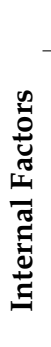 } & Strengths (S) & Weaknesses (W) \\
\hline & 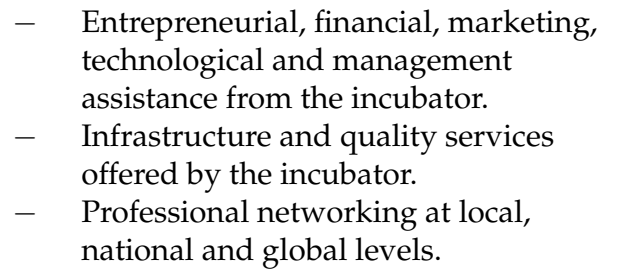 & $\begin{array}{ll}- & \text { Little expertise of the members. } \\
- & \text { Low initial financial investment. }\end{array}$ \\
\hline & Opportunities (0) & Threats (T) \\
\hline 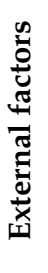 & $\begin{array}{ll}- & \text { Strategic relations with universities and } \\
& \text { research sources. } \\
- & \text { Patent development. } \\
- & \text { Incentives from agencies like SEBRAE } \\
& \text { and ANPROTEC. } \\
- & \text { Access to specific promotion bids. } \\
- & \text { Access to specific credit sources. }\end{array}$ & $\begin{array}{ll}- & \text { Economic/political crisis. } \\
- & \text { Cutting of specific notices for } \\
& \text { development. } \\
- & \text { Exchange variation. } \\
- & \text { Regulatory changes. } \\
- & \text { Inexistence or a low number of clients. }\end{array}$ \\
\hline
\end{tabular}

\subsection{Step 5-Elucidation of Uncertainties}

The uncertainties and their variables are divided into economic, partnerships and structural, as distributed in Table 6. 
Table 6. Uncertainties and variables.

\begin{tabular}{ccl}
\hline Uncertainties & $\#$ & Variables \\
\hline \multirow{3}{*}{ Economic } & $\mathrm{V}_{1}$ & Economic/political crisis \\
& $\mathrm{V}_{2}$ & Access to specific edicts for development \\
& $\mathrm{V}_{3}$ & Exchange variation \\
& $\mathrm{V}_{4}$ & Access to specific credit sources/partnerships \\
& $\mathrm{V}_{5}$ & Initial financial investment \\
\hline \multirow{3}{*}{ Partnership } & $\mathrm{V}_{6}$ & Strategic relations with universities and research sources \\
& $\mathrm{V}_{7}$ & Patent development \\
& $\mathrm{V}_{8}$ & Incentives from agencies like SEBRAE and ANPROTEC \\
\hline \multirow{2}{*}{ Structural } & $\mathrm{V}_{9}$ & Number of clients \\
& $\mathrm{V}_{10}$ & Infrastructure and quality services offered by the incubator \\
\hline
\end{tabular}

\subsection{Step 6-Selection of Relevant Variables}

After identifying the main uncertainties that may influence the future of the sector, the next step is to analyze the relationship between the variables, to identify the impact and dependency of each one, through a cross-impact matrix (Tables 7 and 8).

Table 7. Cross-impact matrix.

\begin{tabular}{cccccccccccc}
\hline$\#$ & $\mathbf{V}_{\mathbf{1}}$ & $\mathbf{V}_{\mathbf{2}}$ & $\mathbf{V}_{\mathbf{3}}$ & $\mathbf{V}_{\mathbf{4}}$ & $\mathbf{V}_{\mathbf{5}}$ & $\mathbf{V}_{\mathbf{6}}$ & $\mathbf{V}_{\mathbf{7}}$ & $\mathbf{V}_{\mathbf{8}}$ & $\mathbf{V}_{\mathbf{9}}$ & $\mathbf{V}_{\mathbf{1 0}}$ & $\boldsymbol{\Sigma}$ \\
\hline $\mathbf{V}_{\mathbf{1}}$ & & -2 & -3 & -3 & -2 & -1 & -2 & -3 & -2 & -1 & -19 \\
\hline $\mathbf{V}_{\mathbf{2}}$ & 0 & & 0 & 1 & 3 & 3 & 3 & 2 & 0 & 2 & 14 \\
\hline $\mathbf{V}_{\mathbf{3}}$ & 0 & 0 & & -1 & -2 & -1 & -1 & -1 & -1 & -1 & -8 \\
\hline $\mathbf{V}_{\mathbf{4}}$ & 0 & 0 & 0 & & 3 & 3 & 3 & 1 & 2 & 3 & 15 \\
\hline $\mathbf{V}_{\mathbf{5}}$ & 0 & 0 & 0 & 0 & & 2 & 1 & 0 & 1 & 0 & 4 \\
\hline $\mathbf{V}_{\mathbf{6}}$ & 0 & -1 & 0 & 0 & 0 & & 3 & 2 & 1 & 1 & 6 \\
\hline $\mathbf{V}_{\mathbf{7}}$ & 0 & 0 & 0 & 1 & 0 & 2 & & 1 & 1 & 1 & 6 \\
\hline $\mathbf{V}_{\mathbf{8}}$ & 1 & 2 & 0 & 3 & 1 & 2 & 3 & & 2 & 3 & 17 \\
\hline $\mathbf{V}_{\mathbf{9}}$ & 0 & 0 & 0 & 2 & 1 & 1 & 0 & 0 & & 0 & 4 \\
\hline $\mathbf{V}_{\mathbf{1 0}}$ & 0 & 1 & 0 & 3 & 0 & 3 & 1 & 2 & 1 & & 11 \\
\hline $\boldsymbol{\Sigma}$ & 1 & 0 & -3 & 6 & 4 & 14 & 11 & 4 & 5 & 8 & 50 \\
\hline
\end{tabular}

Table 8. Assessment scale.

\begin{tabular}{ll}
\hline Degree & Description \\
\hline-3 & Large negative impact \\
-2 & Average negative impact \\
-1 & Small negative impact \\
0 & No impact \\
1 & Small positive impact \\
2 & Average positive impact \\
3 & Large positive impact \\
\hline
\end{tabular}

We obtain the impact value and the dependency for each variable, from the algebraic sum of the rows and columns of the matrix and then we calculate the average impact and dependency, considering absolute values (Table 9). 
Table 9. Impact and dependency values for each variable.

\begin{tabular}{ccc}
\hline Variable & Impact & Dependency \\
\hline $\mathrm{V}_{1}$ & -19 & 1 \\
$\mathrm{~V}_{2}$ & 14 & 0 \\
$\mathrm{~V}_{3}$ & -8 & -3 \\
$\mathrm{~V}_{4}$ & 15 & 6 \\
$\mathrm{~V}_{5}$ & 4 & 4 \\
$\mathrm{~V}_{6}$ & 6 & 14 \\
$\mathrm{~V}_{7}$ & 6 & 11 \\
$\mathrm{~V}_{8}$ & 17 & 4 \\
$\mathrm{~V}_{9}$ & 4 & 5 \\
$\mathrm{~V}_{10}$ & 11 & 8 \\
Average & 10.4 & 5.6 \\
\hline
\end{tabular}

We draw a graph, using the averages of impact and dependency to define the quadrants and then we distribute the values for each variable (Figure 1).

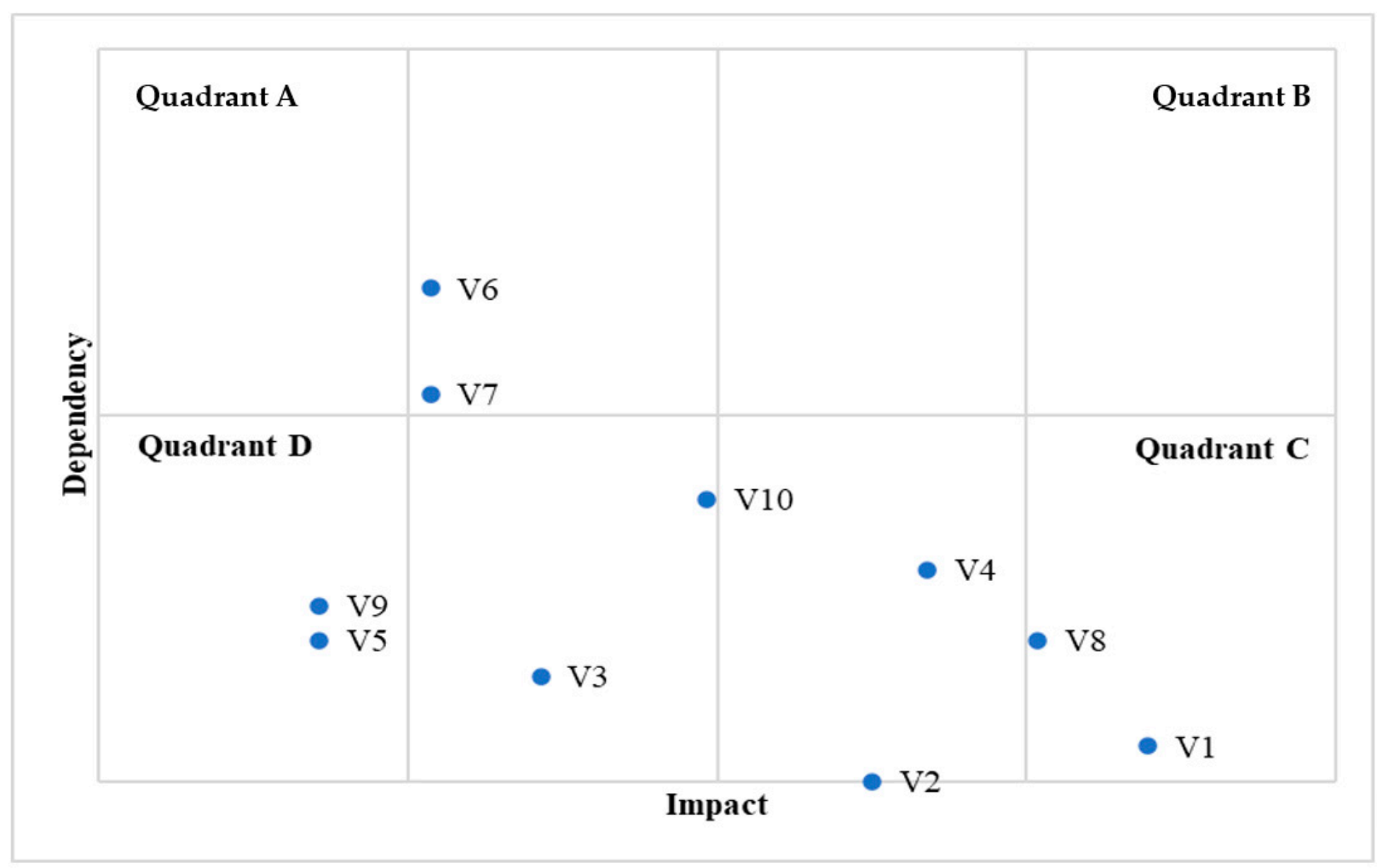

Figure 1. Selection of relevant variables.

According to [10], the large groups of variables are described as follows:

- Quadrant A-Influential variables: very influential and little dependent;

- Quadrant B-Support variables: very influential and highly dependent;

- Quadrant C-Dependent variables: very dependent and not influential;

- Quadrant D-Independent variables: poorly influential and poorly dependent.

The variables in quadrant $\mathrm{D}\left(\mathrm{V}_{3}, \mathrm{~V}_{5}\right.$ and $\left.\mathrm{V}_{9}\right)$, when compared to the others, are considered less relevant, so these variables must be excluded. However, the variable $V_{10}$ was included in this study because, among the four variables in quadrant $\mathrm{D}$, it is the one closest to quadrant $C$. Besides, the theme "Infrastructure and quality services offered by the incubator" was considered very relevant due to the analysis of the variables that could be excluded. Therefore, the relevant variables for this study are: 
- $\quad \mathrm{V}_{1}$-Economic/political crisis

- $\mathrm{V}_{2}$-Access to specific edicts for development

- $\mathrm{V}_{4}$-Access to specific credit sources/partnerships

- $\mathrm{V}_{6}$-Strategic relations with universities and research sources

- $\mathrm{V}_{7}$-Patent development

- $\mathrm{V}_{8}$-Incentives from agencies like SEBRAE and ANPROTEC

- $\mathrm{V}_{10}$-Infrastructure and quality services offered by the incubator

\subsection{Steps 7 and 8-Definition of Key Indicators and Definition of Scenarios}

The variables $\mathrm{V}_{4}, \mathrm{~V}_{7}$ and $\mathrm{V}_{8}$ will also be used as indicators. As it was not possible to obtain the historical series of each variable, the scenarios were defined through morphological analysis of variables. It is worth mentioning the application of such technique to explore all possible solutions to a multidimensional and non-quantifiable problem that has been used by several researchers in the area of future scenarios [38-40]. As a result, three scenarios were built (Table 10), using morphological analysis and considering a five-year horizon.

Table 10. Morphological analysis and scenario building.

\begin{tabular}{lllll}
\hline$\#$ & Variables & Trend & Optimist & Pessimist \\
\hline $\mathbf{V}_{\mathbf{1}}$ & $\begin{array}{l}\text { Economic/political } \\
\text { crisis }\end{array}$ & $\begin{array}{l}\text { Economic/political } \\
\text { crisis remains }\end{array}$ & $\begin{array}{l}\text { Improvement in } \\
\text { economics and } \\
\text { politics }\end{array}$ & $\begin{array}{l}\text { Increased } \\
\text { economic/political } \\
\text { crisis }\end{array}$ \\
\hline $\mathbf{V}_{\mathbf{2}} \begin{array}{l}\text { Access to specific } \\
\text { bids for } \\
\text { development }\end{array}$ & $\begin{array}{l}\text { Maintenance of } \\
\text { specific bids for } \\
\text { development }\end{array}$ & $\begin{array}{l}\text { Increase in the } \\
\text { number of specific } \\
\text { bids for } \\
\text { development }\end{array}$ & $\begin{array}{l}\text { Cut in specific } \\
\text { notices of } \\
\text { development }\end{array}$ \\
\hline $\mathbf{V}_{\mathbf{4}}$ & $\begin{array}{l}\text { Access to specific } \\
\text { credit } \\
\text { sources/partnerships }\end{array}$ & $\begin{array}{l}\text { Maintenance of } \\
\text { credit sources and } \\
\text { partnerships }\end{array}$ & $\begin{array}{l}\text { New } \\
\text { sources/partnerships } \\
\text { for specific credits }\end{array}$ & $\begin{array}{l}\text { Extinction of specific } \\
\text { credit } \\
\text { sources/partnerships }\end{array}$ \\
\hline $\mathbf{V}_{\mathbf{6}}$ & $\begin{array}{l}\text { Strategic relations } \\
\text { with universities } \\
\text { and research } \\
\text { sources. }\end{array}$ & $\begin{array}{l}\text { Staying in strategic } \\
\text { relations with } \\
\text { universities and } \\
\text { research sources }\end{array}$ & $\begin{array}{l}\text { Increased access to } \\
\text { universities and } \\
\text { laboratories }\end{array}$ & $\begin{array}{l}\text { Restrictions on } \\
\text { access to } \\
\text { universities and } \\
\text { research sources }\end{array}$ \\
\hline \\
$\mathbf{V}_{\mathbf{7}} \begin{array}{l}\text { Development of } \\
\text { patents }\end{array}$ & $\begin{array}{l}\text { Access to patent } \\
\text { development } \\
\text { belongs }\end{array}$ & $\begin{array}{l}\text { Increased access to } \\
\text { patent development }\end{array}$ & $\begin{array}{l}\text { Increased } \\
\text { bureaucracy and } \\
\text { delays in patent } \\
\text { development }\end{array}$ \\
\hline
\end{tabular}

\section{Application of AHP-TOPSIS-2N Method}

5.1. Steps 9, 10 and 11-Definition of Criteria, Elicitation of Alternatives and Definition of Weights for Each Criterion of all the Scenarios

The criteria for evaluating the alternatives were defined based on the study by [41] and the doctoral research by [42], which analyzed the public notices for the selection of companies to be incubated by mixed incubators (Table 11). 
Table 11. Criteria for evaluation [43].

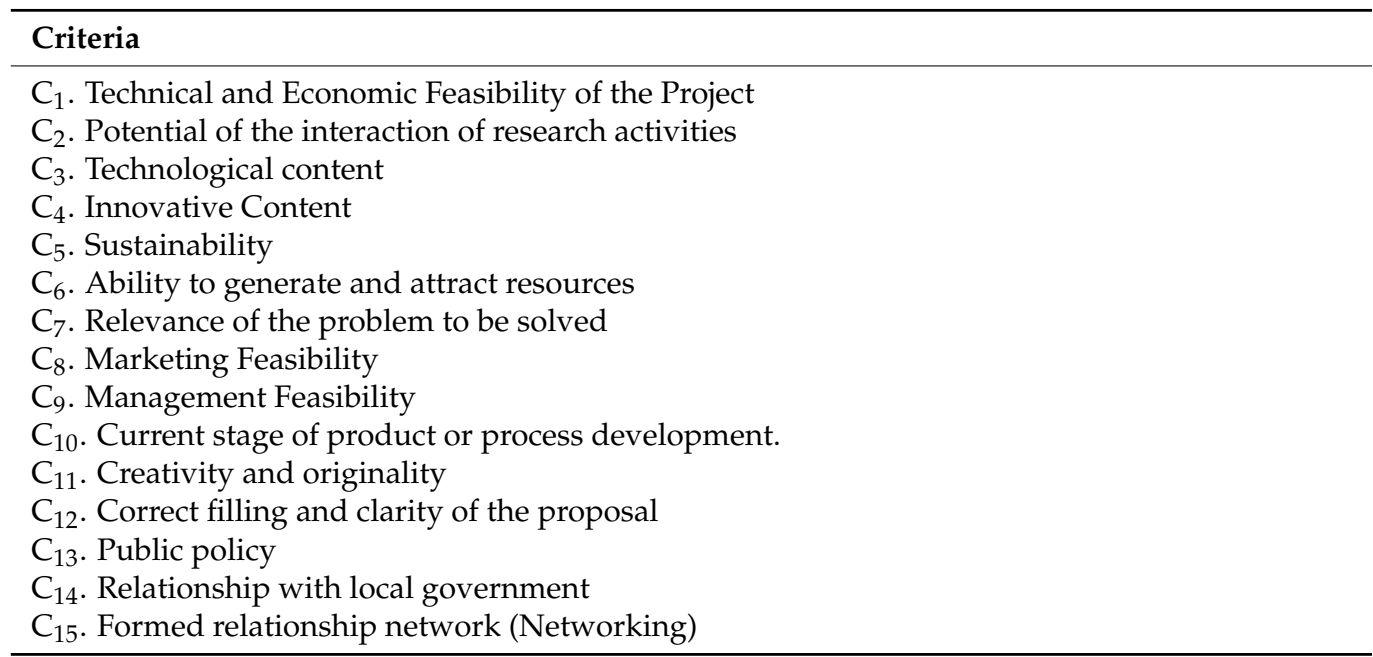

The alternatives are the six companies to be incubated, named $A_{1}, A_{2}, A_{3}, A_{4}, A_{5}$ and $A_{6}$. To obtain the weight of each criterion, the pairwise comparison is made alongside the criteria, through the AHP method, by the DM, who, after consensus, evaluated the scores, observing the Saaty fundamental scale. Table 12 illustrates the pairwise comparison between the criteria for the trend scenario.

Table 12. Pairwise comparison matrix.

\begin{tabular}{cccccccccccccccc}
\hline & $\mathrm{C}_{\mathbf{1}}$ & $\mathrm{C}_{\mathbf{2}}$ & $\mathrm{C}_{\mathbf{3}}$ & $\mathrm{C}_{\mathbf{4}}$ & $\mathrm{C}_{\mathbf{5}}$ & $\mathrm{C}_{\mathbf{6}}$ & $\mathrm{C}_{\mathbf{7}}$ & $\mathrm{C}_{\mathbf{8}}$ & $\mathrm{C}_{9}$ & $\mathrm{C}_{\mathbf{1 0}}$ & $\mathrm{C}_{\mathbf{1 1}}$ & $\mathrm{C}_{\mathbf{1 2}}$ & $\mathrm{C}_{\mathbf{1 3}}$ & $\mathrm{C}_{\mathbf{1 4}}$ & $\mathrm{C}_{\mathbf{1 5}}$ \\
\hline $\mathrm{C}_{\mathbf{1}}$ & 1 & 3 & $1 / 3$ & 2 & 2 & $1 / 2$ & 2 & 4 & 2 & 5 & 2 & 4 & 4 & 2 & 2 \\
$\mathrm{C}_{\mathbf{2}}$ & $1 / 3$ & 1 & $1 / 2$ & 3 & 2 & 1 & $1 / 3$ & $1 / 2$ & $1 / 3$ & $1 / 2$ & 2 & 2 & 2 & 2 & 2 \\
$\mathrm{C}_{\mathbf{3}}$ & 3 & 2 & 1 & 1 & 2 & $1 / 2$ & $1 / 2$ & 2 & 2 & 2 & 3 & 4 & 3 & 2 & 3 \\
$\mathrm{C}_{\mathbf{4}}$ & $1 / 2$ & $1 / 3$ & 1 & 1 & 2 & 1 & 1 & 1 & 3 & 2 & 2 & 3 & 3 & 4 & 2 \\
$\mathrm{C}_{\mathbf{5}}$ & $1 / 2$ & $1 / 2$ & $1 / 2$ & $1 / 2$ & 1 & $1 / 2$ & $1 / 3$ & $1 / 2$ & $1 / 2$ & 2 & 1 & $1 / 3$ & 4 & 3 & 4 \\
$\mathrm{C}_{\mathbf{6}}$ & 2 & 1 & 2 & 1 & 2 & 1 & 3 & 3 & 2 & 2 & 1 & 1 & 3 & 2 & 2 \\
$\mathrm{C}_{\mathbf{7}}$ & $1 / 2$ & 3 & 2 & 1 & 3 & $1 / 3$ & 1 & 2 & 4 & 3 & 1 & 1 & 3 & 2 & 2 \\
$\mathrm{C}_{\mathbf{8}}$ & $1 / 4$ & 2 & $1 / 2$ & 1 & 2 & $1 / 3$ & $1 / 2$ & 1 & 2 & 3 & 2 & $1 / 2$ & 2 & 2 & 1 \\
$\mathrm{C}_{\mathbf{9}}$ & $1 / 2$ & 3 & $1 / 2$ & $1 / 3$ & 2 & $1 / 2$ & $1 / 4$ & $1 / 2$ & 1 & 2 & $1 / 3$ & $1 / 3$ & 1 & 1 & $1 / 2$ \\
$\mathrm{C}_{\mathbf{1 0}}$ & $1 / 5$ & 2 & $1 / 2$ & $1 / 2$ & $1 / 2$ & $1 / 2$ & $1 / 3$ & $1 / 3$ & $1 / 2$ & 1 & $1 / 2$ & $1 / 3$ & $1 / 3$ & 2 & 2 \\
$\mathrm{C}_{\mathbf{1 1}}$ & $1 / 2$ & $1 / 2$ & $1 / 3$ & $1 / 2$ & 1 & 1 & 1 & $1 / 2$ & 3 & 2 & 1 & 2 & 2 & 2 & 1 \\
$\mathrm{C}_{\mathbf{1 2}}$ & $1 / 4$ & $1 / 2$ & $1 / 4$ & $1 / 3$ & 3 & 1 & 1 & 2 & 3 & 3 & $1 / 2$ & 1 & 3 & 2 & $1 / 3$ \\
$\mathrm{C}_{\mathbf{1 3}}$ & $1 / 4$ & $1 / 2$ & $1 / 3$ & $1 / 3$ & $1 / 4$ & $1 / 3$ & $1 / 3$ & $1 / 2$ & 1 & 3 & $1 / 2$ & $1 / 3$ & 1 & 2 & 2 \\
$\mathrm{C}_{\mathbf{1 4}}$ & $1 / 2$ & $1 / 2$ & $1 / 2$ & $1 / 4$ & $1 / 3$ & $1 / 2$ & $1 / 2$ & $1 / 2$ & 1 & $1 / 2$ & $1 / 2$ & $1 / 2$ & $1 / 2$ & 1 & 3 \\
$\mathrm{C}_{\mathbf{1 5}}$ & $1 / 2$ & $1 / 2$ & $1 / 3$ & $1 / 2$ & $1 / 4$ & $1 / 2$ & $1 / 2$ & 1 & 2 & $1 / 2$ & 1 & 3 & $1 / 2$ & $1 / 3$ & 1 \\
\hline
\end{tabular}

The obtained CR value was 0.0789 , which is lower than the minimum acceptable value of 0.1. Therefore, the values of the weights obtained after the analysis of the DM can be considered consistent. The pairwise comparison was made to all analyzed scenarios (trend, optimistic and pessimistic), presenting CR lower than 0.1. Table 13 shows the weights of the criteria for each scenario analyzed. 
Table 13. Weights of criteria.

\begin{tabular}{lcccc}
\hline & Criteria & \multicolumn{3}{c}{ Weight } \\
\cline { 3 - 5 } & & Trend & Optimist & Pessimist \\
\hline$C_{1}$ & Technical and Economic Feasibility of the Project & 0.1135 & 0.1007903 & 0.058824 \\
$C_{2}$ & Potential of interaction of research activities & 0.0681 & 0.0604742 & 0.050074 \\
$C_{3}$ & Technological content & 0.1046 & 0.092887 & 0.076912 \\
$C_{4}$ & Innovative Content & 0.0845 & 0.1065625 & 0.066176 \\
$C_{5}$ & Sustainability & 0.0549 & 0.0799219 & 0.029412 \\
$C_{6}$ & Ability to generate and attract resources & 0.1034 & 0.1411065 & 0.080882 \\
$C_{7}$ & Relevance of the problem to be solved & 0.0918 & 0.0815203 & 0.0675 \\
$C_{8}$ & Marketing Feasibility & 0.0614 & 0.0545245 & 0.045147 \\
$C_{9}$ & Management Feasibility & 0.0444 & 0.0394281 & 0.044118 \\
$C_{10}$ & Current stage of product or process development. & 0.0374 & 0.033212 & 0.051471 \\
$C_{11}$ & Creativity and originality & 0.0582 & 0.0516828 & 0.066176 \\
$C_{12}$ & Correct filling and clarity of the proposal & 0.0641 & 0.0569221 & 0.047132 \\
$C_{13}$ & Public policy & 0.0365 & 0.0324128 & 0.125 \\
$C_{14}$ & Relationship with local government & 0.0352 & 0.0312583 & 0.102941 \\
$C_{15}$ & Formed relationship network (Networking) & 0.042 & 0.0372969 & 0.088235 \\
\hline
\end{tabular}

Analyzing the weights of the criteria, we observed that the variations in the values are quite considerable because each scenario provides different priorities and variables to be considered by DM in the elicitation of weights through pairwise comparison. In general, in the trend and optimist scenarios, the criteria $C_{1}, C_{3}, C_{6}$ and $C_{7}$ were more important, mainly because they are more related to the business capacity of each company.

In the pessimistic scenario, the Criteria $C_{13}, C_{14}$ and $C_{15}$ stand out, because, in a pessimistic scenario of crisis, external and network political factors are essential for the success of the enterprises.

\subsection{Step 12-Evaluation of the Alternatives from the Point of View of Each Criterion}

The six alternatives (companies to be incubated) were evaluated by the consultants of the business incubator (Incubator X). For each criterion a score of 1 to 5 was defined, following the scale:

1. Does not meet;

2. Partially meets;

3. Meets;

4. Partially exceeds,

5. Exceeds.

Table 14 presents the scores defined by the consultants for each criterion.

Table 14. Scoring of alternatives for each criterion of Incubator X.

\begin{tabular}{cccccccccccccccc}
\hline $\begin{array}{c}\text { Criteria/ } \\
\text { Alternatives }\end{array}$ & $\mathbf{C}_{\mathbf{1}}$ & $\mathbf{C}_{\mathbf{2}}$ & $\mathbf{C}_{\mathbf{3}}$ & $\mathbf{C}_{\mathbf{4}}$ & $\mathbf{C}_{\mathbf{5}}$ & $\mathbf{C}_{\mathbf{6}}$ & $\mathbf{C}_{\mathbf{7}}$ & $\mathbf{C}_{\mathbf{8}}$ & $\mathbf{C}_{\mathbf{9}}$ & $\mathbf{C}_{\mathbf{1 0}}$ & $\mathbf{C}_{\mathbf{1 1}}$ & $\mathbf{C}_{\mathbf{1 2}}$ & $\mathbf{C}_{\mathbf{1 3}}$ & $\mathbf{C}_{\mathbf{1 4}}$ & $\mathbf{C}_{\mathbf{1 5}}$ \\
\hline $\mathbf{A}_{\mathbf{1}}$ & 5 & 5 & 5 & 3 & 3 & 5 & 1 & 3 & 2 & 2 & 3 & 2 & 2 & 2 & 2 \\
$\mathbf{A}_{\mathbf{2}}$ & 5 & 1 & 1 & 1 & 1 & 4 & 3 & 1 & 1 & 1 & 5 & 5 & 5 & 1 & 5 \\
$\mathbf{A}_{\mathbf{3}}$ & 5 & 4 & 5 & 4 & 3 & 3 & 5 & 5 & 3 & 2 & 1 & 2 & 1 & 1 & 1 \\
$\mathbf{A}_{\mathbf{4}}$ & 3 & 4 & 3 & 3 & 2 & 4 & 4 & 4 & 4 & 4 & 1 & 3 & 3 & 3 & 2 \\
$\mathbf{A}_{\mathbf{5}}$ & 5 & 3 & 5 & 3 & 4 & 5 & 4 & 3 & 5 & 4 & 4 & 5 & 5 & 1 & 3 \\
$\mathbf{A}_{\mathbf{6}}$ & 2 & 2 & 4 & 2 & 5 & 5 & 3 & 3 & 3 & 5 & 4 & 3 & 1 & 4 & 2 \\
\hline
\end{tabular}

\subsection{Step 13-Ordering the Alternatives in Each Scenario}

We applied the AHP-TOPSIS $2 \mathrm{~N}$ method, considering the three scenarios. To obtain $\mathrm{D}+, \mathrm{D}-$ and score $(\mathrm{C})$ values, we applied Equations (7)-(9) respectively. In the trend scenario, the companies were ordered as demonstrated in Table 15. 
Table 15. Ordering trend scenario.

\begin{tabular}{cccccccc}
\hline \multicolumn{7}{c}{ Scenario 1: Trend } \\
\hline \multicolumn{7}{c}{ Normalization $\mathbf{N}_{\mathbf{2}}$} \\
Alternative & $\mathrm{D}+$ & $\mathrm{D}-$ & Score & Alternative & $\mathrm{D}+$ & $\mathrm{D}-$ & Score \\
$\mathrm{A}_{5}$ & 0.0368 & 0.0879 & 0.7046 & $\mathrm{~A}_{5}$ & 0.0748 & 0.2383 & 0.7611 \\
$\mathrm{~A}_{3}$ & 0.0591 & 0.0876 & 0.5969 & $\mathrm{~A}_{1}$ & 0.1416 & 0.2131 & 0.6007 \\
$\mathrm{~A}_{1}$ & 0.0645 & 0.0743 & 0.5354 & $\mathrm{~A}_{3}$ & 0.1576 & 0.217 & 0.5793 \\
$\mathrm{~A}_{4}$ & 0.0575 & 0.0645 & 0.5284 & $\mathrm{~A}_{6}$ & 0.1651 & 0.172 & 0.5103 \\
$\mathrm{~A}_{6}$ & 0.0635 & 0.0658 & 0.5087 & $\mathrm{~A}_{4}$ & 0.1468 & 0.1517 & 0.5081 \\
$\mathrm{~A}_{2}$ & 0.0864 & 0.0614 & 0.4156 & $\mathrm{~A}_{2}$ & 0.1972 & 0.1681 & 0.4602 \\
\hline
\end{tabular}

Company $\mathrm{A}_{5}$ had a better evaluation, with similar results in the two normalizations; we emphasize the scores obtained by this alternative, with a considerable relative difference for the other companies in the two normalizations. Company $\mathrm{A}_{2}$ received the worst evaluations. The other alternatives presented variations in their ordering in both scenarios.

Applying the same procedure for calculating the scores, we obtain the Optimist and pessimist scenarios ordering (Table 16).

Table 16. Optimist and pessimist scenarios ordering.

\begin{tabular}{|c|c|c|c|c|c|c|c|}
\hline \multicolumn{4}{|c|}{ Scenario 2: Optimist } & \multicolumn{4}{|c|}{ Scenario 3: Pessimist } \\
\hline \multicolumn{2}{|c|}{ Normalization $\mathbf{N}_{2}$} & \multicolumn{2}{|c|}{ Normalization $\mathbf{N}_{4}$} & \multicolumn{2}{|c|}{ Normalization $\mathrm{N}_{2}$} & \multicolumn{2}{|c|}{ Normalization $\mathrm{N}_{4}$} \\
\hline $\mathrm{A}_{5}$ & 0.6806 & $\mathrm{~A}_{5}$ & 0.7214 & $\mathrm{~A}_{5}$ & 0.7206 & $\mathrm{~A}_{5}$ & 0.6914 \\
\hline $\mathrm{A}_{4}$ & 0.6169 & $\mathrm{~A}_{1}$ & 0.6207 & $\mathrm{~A}_{1}$ & 0.6367 & $\mathrm{~A}_{3}$ & 0.6007 \\
\hline $\mathrm{A}_{6}$ & 0.555 & $\mathrm{~A}_{6}$ & 0.5323 & $\mathrm{~A}_{4}$ & 0.5757 & $\mathrm{~A}_{4}$ & 0.5513 \\
\hline $\mathrm{A}_{1}$ & 0.504 & $\mathrm{~A}_{3}$ & 0.5203 & $\mathrm{~A}_{3}$ & 0.5245 & $\mathrm{~A}_{6}$ & 0.5403 \\
\hline $\mathrm{A}_{3}$ & 0.4887 & $\mathrm{~A}_{4}$ & 0.5011 & $\mathrm{~A}_{6}$ & 0.4982 & $\mathrm{~A}_{1}$ & 0.5311 \\
\hline $\mathrm{A}_{2}$ & 0.4156 & $\mathrm{~A}_{2}$ & 0.4502 & $\mathrm{~A}_{2}$ & 0.4356 & $\mathrm{~A}_{2}$ & 0.4802 \\
\hline
\end{tabular}

In the optimist scenario, company $\mathrm{A}_{2}$ was also ranked first, but with a smaller relative difference for the other alternatives. In the same way, as in scenario 1 , the alternative $\mathrm{A}_{2}$ obtained the worst performance and the other ones presented great variations in scores and ordering. The result of the pessimistic scenario corroborates those of the optimistic and trend scenarios, where company $\mathrm{A}_{5}$ is the best classified and $\mathrm{A}_{2}$ had the worst results.

Based on these results, we can cluster the alternatives in the following groups:

- Group: 1 alternative $A_{5}$;

- Group 2: alternatives $\mathrm{A}_{1}, \mathrm{~A}_{3}, \mathrm{~A}_{4}$ and $\mathrm{A}_{6}$;

- Group 3: alternative $\mathrm{A}_{2}$.

Analyzing the groups, it is observed that the $A_{5}$ alternative can be selected as the company to be incubated, because it obtained the best ordering in both normalizations for all scenarios analyzed. We emphasize that each scenario presented a distribution of weights of the criteria, which makes the selection of this alternative as the best solution to the proposed problem.

Analyzing the results obtained, the alternative $\mathrm{A}_{5}$ presented the best classifications in both standardization processes because it had the best performances in six of the fifteen criteria, including those with the highest weights after analysis by the DM. On the other hand, alternative $\mathrm{A}_{2}$, which obtained the worst ordering, presented the worst performance in eight of the fifteen criteria.

Besides, the fact that we analyzed three scenarios (with different weights of criteria for each situation), combined with the two normalizations of the AHP-TOPSIS-2N method provides richer and more robust sensitivity analysis, allowing us to observe the behavior of alternatives in both scenarios. This characteristic gives more transparency to the decisionmaking process about a complex problem, such as the object of this research. 
It must be highlighted that the final ranking depends on the number of vacancies offered by each business incubator. AHP-TOPSIS 2N always allows DM to go back to previous steps to review key information, perform sensitivity analyzes, assess the impact of project weights and scores, and adjust scales; until it reaches the proper stability for the application of the method.

\section{Conclusions}

Increasingly, the role of business incubators has become essential for generating new business. Works related to the theme must be developed to improve or create methods that help them or improve their performance. We did not find in the literature any study that uses prospective scenarios with a multicriteria method to evaluate companies to be incubated.

In this sense, this research proposed a model to evaluate the business project of companies that are candidates for incubation, considering prospective scenarios and the AHP-TOPSIS-2N MCDM method to rank the companies to be incubated. This proposed algorithm presented robust and reliable results, with a sensitivity analysis of the results in various scenarios, with the selection of the Alternative $A_{5}$ as the company to be incubated.

The AHP-TOPSIS-2N method proved to be efficient for the proposed analysis, enabling the achievement of the criteria weights, in addition to the robustness generated by the proximity analysis of the Positive Ideal Solution.

The proposed criteria and the ranking method are an attempt to improve the existing models used by the incubators. Therefore, we include scenario analysis to create an initial core of criteria and a hybrid MCDM method for evaluating incubation projects.

The prospective scenarios study, through the application of the Momentum method, provided a detailed study of the uncertainties and variables that impact the future of the company, helping to reduce uncertainties, presenting possible actions to increase efficiency and effectiveness in the processes. The hybrid methodology-Momentum and AHPTOPSIS-2N-proved to be very effective, because, in addition to defining several analysis scenarios, it provided support for strategic decision-making.

The strategic study, carried out through the application of tools such as the SWOT matrix, stakeholder analysis and cross-impact matrix, provided a simple and transparent understanding of the internal and external variables that influence the company's processes.

Given the above, it is clear that the prospective scenarios combined with MCDM methods can increase the quality of the decision-making process, because, as evidenced in the case study, this hybrid methodology offers a well-structured analysis of criteria and alternatives, contributing to a more transparent, robust and reliable decision-making.

We hope that our model can assist incubator managers in this process. We highlight that our model can be used and/or adapted to solve the most diverse real problems of daily life, being a very useful method to support high-level decision-making in operational, tactical and strategic problems.

Author Contributions: Conceptualization, A.S.O., C.F.S.G. and M.S.; methodology, A.S.O., C.T.C., A.M.S.; software, M.R.S.B., I.P.A.C., and M.S.; validation, C.F.S.G. and M.S.; writing-original draft preparation, A.S.O., A.M.S. and I.P.A.C.; writing-review and editing, C.F.S.G. and M.S.; supervision, C.F.S.G. All authors have read and agreed to the published version of the manuscript.

Funding: This research received no external funding.

Data Availability Statement: Not Applicable, the study does not report any data.

Conflicts of Interest: The authors declare no conflict of interest.

\section{References}

1. Eschholz, V.; Silva, M.C.; Rampasso, I.S.; Anholon, R.; Ordonez, R.E.C. Primary criteria used by business incubators for the selection of new enterprises: Analysis of selection notices. Brazilian J. Oper. Prod. Manag. 2018, 15, 224-231. [CrossRef]

2. de Souza, T.F.; Gomes, C.F.S. Assessment of maturity in project management: A bibliometric study of main models. Procedia Comput. Sci. 2015, 55, 92-101. [CrossRef] 
3. Maestripieri, N.; Houet, T.; Paegelow, M.; Selleron, G.; Balbontin, D.T.; Villalobos, N.S. Dynamic Simulation of Forest Management Normative Scenarios: The Case of Timber Plantations in the Southern Chile; Elsevier: Amsterdam, The Netherlands, 2017; Volume 87, pp. 65-77.

4. de Carvalho, A.L.; Antunes, C.H.; Freire, F. Economic-energy-environment analysis of prospective sugarcane bioethanol production in Brazil. Appl. Energy 2016, 181, 514-526. [CrossRef]

5. Delmotte, S.; Lopez-Ridaura, S.; Barbier, J.-M.; Wery, J. Prospective and participatory integrated assessment of agricultural systems from farm to regional scales: Comparison of three modeling approaches. J. Environ. Manag. 2013, 129, 493-502. [CrossRef]

6. Moreau, P.; Ruiz, L.; Raimbault, T.; Vertès, F.; Cordier, M.-O.; Gascuel-Odoux, C.; Masson, V.; Salmon-Monviola, J.; Durand, P. Modeling the potential benefits of catch-crop introduction in fodder crop rotations in a Western Europe landscape. Sci. Total Environ. 2012, 437, 276-284. [CrossRef]

7. Wulung, R.B.S.; Takahashi, K.; Morikawa, K.; Hamada, K.; Cakravastia, A.; Diawaiti, L.A. The multicriteria incubator selection model by considering investor orientation. In Proceedings of the 11th International Conference on Industrial Management, Tokyo, Japan, 29-31 August 2012.

8. Frischknecht, R.; Büsser, S.; Krewitt, W. Environmental assessment of future technologies: How to trim LCA to fit this goal? Int. J. Life Cycle Assess. 2009, 14, 584-588. [CrossRef]

9. Schwartz, M.; Göthner, M. A multidimensional evaluation of the effectiveness of business incubators: An application of the PROMETHEE outranking method. Environ. Plan. C Gov. Policy 2009, 27, 1072-1087. [CrossRef]

10. Gomes, C.F.S.; Costa, H.G.; de Barros, A.P. Sensibility analysis of MCDA using prospective in Brazilian energy sector. J. Model. Manag. 2017, 12, 475-497. [CrossRef]

11. De Souza, L.P.; Gomes, C.F.S.; De Barros, A.P. Implementation of New Hybrid AHP-TOPSIS-2N Method in Sorting and Prioritizing of an it CAPEX Project Portfolio. Int. J. Inf. Technol. Decis. Mak. 2018, 17, 977-1005. [CrossRef]

12. Moreira, J. Modelo de Gestão Para Incubação de Empresas Orientado a Capital de Risco; Universidade Federal de Santa Catarina: Lorianópolis, Brazil, 2002.

13. Schwartz, M. Beyond incubation: An analysis of firm survival and exit dynamics in the post-graduation period. J. Technol. Transf. 2009, 34, 403-421. [CrossRef]

14. Moeen, M.; Agarwal, R. Incubation of an industry: Heterogeneous knowledge bases and modes of value capture. Strateg. Manag. J. 2017, 38, 566-587. [CrossRef]

15. Dantas, M.K.; de Oliveira, L.R.; Ferolla, L.M.; Paschoalotto, M.A.C.; Lopes, J.E.F.; Passador, J.L.; Passador, C.S. Cross-sectoral assessment of public policies in health and the environment: Scenario of the municipalities in the state of Sao Paulo. Eval. Program Plan. 2017, 65, 30-39. [CrossRef] [PubMed]

16. Schoemaker, P.J.H. Scenario planning: A tool for strategic thinking. Sloan Manag. Rev. 1995, 36, 25-50.

17. Gomes, L.; Gomes, C.F.S. Princípios e Métodos Para a Tomada de Decisão: Enfoque Multicritério; Atlas: São Paulo, Brazil, 2019.

18. De Carvalho Pereira, F.; Verocai, H.D.; Cordeiro, V.R.; Gomes, C.F.S.; Costa, H.G. Bibliometric Analysis of Information Systems Related to Innovation; Elsevier: Amsterdam, The Netherlands; Universidade Federal Fluminense-UFF: Rio de Janeiro, Brazil, 2015; Volume 55, pp. 298-307.

19. Wang, J.; Fan, K.; Su, Y.; Liang, S.; Wang, W. Air Combat Effectiveness Assessment of Military Aircraft Using a Fuzzy AHP and TOPSIS Methodology; School of Mechanical Engineering and Automation, Northeastern University: Shenyang, China, 2008 ; pp. 655-662.

20. Sánchez-Lozano, J.M.; Serna, J.; Dolón-Payán, A. Evaluating military training aircrafts through the combination of multi-criteria decision making processes with fuzzy logic. A case study in the Spanish Air Force Academy. Aerosp. Sci. Technol. 2015, $42,58-65$. [CrossRef]

21. Kiracı, K.; Akan, E. Aircraft selection by applying AHP and TOPSIS in interval type-2 fuzzy sets. J. Air Transp. Manag. 2020, 89. [CrossRef]

22. Gomes, L.; Mury, A.-R.; Gomes, C.F.S. Multicriteria ranking with ordinal data. Syst. Anal. 1997, $27,139-146$.

23. Cardoso, R.S.; Xavier, L.H.; Gomes, C.F.S.; Adissi, P.J. Uso de SAD no apoio à decisão na destinação de resíduos plásticos e gestão de materiais. Pesqui. Operacional 2009, 29, 67-95. [CrossRef]

24. dos Santos, M.; Quintal, R.S.; da Paixão, A.C.; Gomes, C.F.S. Simulation of operation of an integrated information for emergency pre-hospital care in Rio de Janeiro municipality. Procedia Comput. Sci. 2015, 55, 931-938. [CrossRef]

25. de Costa, I.P.A.; Sanseverino, A.M.; dos Barcelos, M.R.S.; Belderrain, M.C.N.; Gomes, C.F.S.; Santos, M. Choosing flying hospitals in the fight against the COVID-19 pandemic: Structuring and modeling a complex problem using the VFT and ELECTRE-MOr methods. IEEE Lat. Am. Trans. 2021, 19, 1099-1106.

26. De Costa, I.P.A.; Maêda, S.M.N.; Teixeira, L.F.H.; Gomes, C.F.S.; Santos, M. Choosing a hospital assistance ship to fight the Covid-19 pandemic. Rev. Saude Publica 2020, 54. [CrossRef]

27. Tenório, F.M.; dos Santos, M.; Gomes, C.F.S.; de Carvalho Araujo, J. Navy Warship Selection and Multicriteria Analysis: The THOR Method Supporting Decision Making. In International Joint conference on Industrial Engineering and Operations Management; Springer: Berlin/Heidelberg, Germany, 2020; pp. 27-39.

28. Moreira, M.Â.L.; Gomes, C.F.S.; dos Santos, M.; do Carmo Silva, M.; Araujo, J.V.G.A. PROMETHEE-SAPEVO-M1 a Hybrid Modeling Proposal: Multicriteria Evaluation of Drones for Use in Naval Warfare; Springer: Berlin/Heidelberg, Germany; Military Institute of Engineering (IME): Urca, Brazil, 2020; Volume 337, pp. 381-393. 
29. Vavrek, R.; Bečica, J.; Papcunová, V.; Gundová, P.; Mitríková, J. Number of Financial Indicators as a Factor of Multi-Criteria Analysis via the TOPSIS Technique: A Municipal Case Study. Algorithms 2021, 14, 64. [CrossRef]

30. dos Santos, M.; de Costa, I.P.A.; Gomes, C.F.S. Sensitivity analysis of multicriteria decision between standard deviation and average in the selection of construction of warships: A new approach to the AHP method. Int. J. Anal. Hierarchy Process. $2021,1,1$.

31. Saaty, T.L. The Analytic Hierarchy Process: Planning, Priority Setting, Resource Allocation; McGraw-Hill. Inc.: New York, NY, USA, 1980.

32. García, J.L.; Alvarado, A.; Blanco, J.; Jiménez, E.; Maldonado, A.A.; Cortés, G. Multi-attribute evaluation and selection of sites for agricultural product warehouses based on an analytic hierarchy process. Comput. Electron. Agric. 2014, 100, 60-69. [CrossRef]

33. Hwang, C.-L.; Yoon, K. Methods for multiple attribute decision making. In Multiple Attribute Decision Making; Springer: Berlin/Heidelberg, Germany, 1981; pp. 58-191.

34. Roselli, L.R.P.; Almeida, A.T. Modelo Multicritério de Seleção de Fornecedores com Base no Método Topsis com Números Grey [Topsis Multicriteria Supplier Selection Model Based on Grey Numbers Method]. XLVII SBPO Simpósio Bras. Pesqui. Operacional 2015, 20, 470-481.

35. Gomes, L.; Gomes, C.F.S.C.F.S.; da Luz, A.A.; Kovaleski, J.L.; dos Reis, D.R.; de Andrade Júnior, P.P.; Zammar, A.; Maestripieri, N.; Houet, T.; Paegelow, M.; et al. Dynamic simulation of forest management normative scenarios: The case of timber plantations in the southern Chile. Futures 2015, 38, 65-77.

36. Dolabela, F. Oficina do empreendedor [Entrepreneur Workshop]; Cultura: São Paulo, Brazil, 1999.

37. ANPROTEC Economic Impact Study: Business Incubators Segment in Brazil. Available online: https://www.anprotec.org.br/ Relata/18072016Estudo_ANPROTEC_v6.pdf (accessed on 10 September 2020).

38. Durance, P.; Godet, M. Scenario building: Uses and abuses. Technol. Forecast. Soc. Change 2010, 77, 1488-1492. [CrossRef]

39. Börjeson, L.; Höjer, M.; Dreborg, K.-H.; Ekvall, T.; Finnveden, G. Scenario types and techniques: Towards a user's guide. Futures 2006, 38, 723-739. [CrossRef]

40. Coyle, R.G.; McGlone, G.R. Projecting scenarios for South-east Asia and the South-west Pacific. Futures 1995, 27, 65-79. [CrossRef]

41. Oliveira, A.S.; Gomes, C.F.S.; Barros, M.D.; Barcelos, M.R.S.; Santos, M. Incubadoras de Empresas e Indicadores de Desempenho: Uma Análise Quantitativa da Produção Científica dos Artigos Indexados na Base Scopus [Business Incubators and Performance Indicators: A Quantitative Analysis of the Scientific Production of Scopus Index. XXIV SIMPEP Simpósio Eng. Produção 2017, 21, $1-11$.

42. Oliveira, A. Proposta Metodológica Para Seleção de Empresas a Serem Incubadas: Abordagem Multicritério e Cenários Prospectivos. Available online: https:/ / www.revistasg.uff.br/sg/article/download/1251/861/ (accessed on 26 March 2021).

43. Oliveira, A.S.; de Barros, M.D.; de Carvalho Pereira, F.; Gomes, C.F.S.; da Costa, H.G. Prospective scenarios: A literature review on the Scopus database. Futures 2018, 100, 20-33. [CrossRef] 